\title{
Internationalisation and Cross-Border Mobility in Indian Higher Education
}

\author{
N.V. Varghese*
}

\begin{abstract}
With the end of the Cold War political returns on foreign aid diminished. Many countries came to recognise trade as a more development-friendly modality than aid. Internationalisation of higher education also shifted from aid related cooperation agreements to market mediated cross-border trade arrangements within the framework of the General Agreement on Trade in Services (GATS). This article examines the changing face of internationalisation of higher education with a focus on the Indian experience. It argues that while internationalisation and cross-border mobility are mediated by market processes and economic rationality in most countries, the Indian government's initiatives to internationalise Indian higher education are motivated by extending diplomatic relations to enable the country to play a more prominent role in global affairs.
\end{abstract}

Key words: Cross-border education, internationalisation, globalisation, commodification, Africanisation, value maximisers

Avec la fin de la Guerre froide, les retours politiques sur l'aide internationale ont diminué. Beaucoup de pays en sont venus à reconnaître le commerce comme une modalité plus propice au développement que l'aide. L'internationalisation de l'Enseignement supérieur a aussi basculé d'accords de coopération liés à l'aide vers des arrangements commerciaux transfrontaliers arbitrés par le marché dans le cadre de l’Accord général sur le commerce des services (GATS en anglais pour « General Agreement on Trade in Services »). Cet article examine le changement de profil de

\footnotetext{
* The opinions and views expressed in this article are those of the author and should not necessarily be attributed to this institution.
}

ABOUT THE AUTHOR: N.V. VARGHESE Vice-Chancellor, National Institute of Educational Planning and Administration, New Delhi. Email: nv.varghese@niepa.ac.in 
l'internationalisation de l'Enseignement supérieur avec un point focal sur l'expérience indienne. Il affirme que, tandis que l'internationalisation et la mobilité transfrontalière sont arbitrés par les mécanismes de marché et la rationalité économique dans la plupart des pays, les initiatives du gouvernement indien pour l'internationalisation de l'Enseignement supérieur indien sont motivées par l'extension des relations diplomatiques afin de permettre au pays de jouer un rôle plus important sur la scène internationale.

Mots clés: enseignement transfrontalier, internationalisation, mondialisation, marchandisation, Africanisation, optimisateurs de valeur

\section{Introduction}

In the post-World War II period, development strategy was characterised by two seemingly conflicting trends - protectionism and international cooperation. Many development economists were sceptical about relying on markets for the development of poor countries and argued in favour of protectionism and state-led planning. Most post-colonial leaders in developing countries were educated in Western democracies and found value in international cooperation for national development even under the regime of protectionism (Edwards, 20I4). This resulted in the evolution of foreignaid-led government-to-government agreements to facilitate international cooperation for development.

The political returns on foreign aid remained high during the post-World War and Cold War periods, with Western countries and the Soviet Union competing to extend aid to their allies. While European countries' aid benefitted their former colonies, the US and Soviet Union assisted countries that were aligned with them (Moyo, 2009). With the end of the Cold War, such political returns diminished. Tax payers in some of the rich countries were reluctant to subsidise development in poor countries, with many regarding trade as a more effective and development-friendly modality than aid. International cooperation agreements became more sensitive to economic rationality and market signals. In similar vein, internationalisation of higher education (HE) shifted from aid related cooperation agreements to market mediated cross-border trade arrangements within the framework of the General Agreement on Trade in Services (GATS).

This article examines the changing face of internationalisation of $\mathrm{HE}$ in the context of globalisation with a focus on developments in India. While economic returns and revenue-generating potential are identified as the main factors that influence investment in internationalisation of HE under the GATS framework, this does not hold true for internationalisation efforts in all countries. This article argues that, while efforts to internationalise HE through outward cross-border mobility are motivated by market processes and economic rationality, government initiatives to internationalise Indian $\mathrm{HE}$ are primarily informed by the desire to extend diplomatic relations and to gain an increased global role for the country.

The article is structured as follows: Section 2 argues that internationalisation of HE was regarded as an extension of external support for the national development of the newly independent countries, while section 3 presents changing views on internationalisation in the context of the globalisation of production and trade in education. Section 4 examines different forms of cross-border mobility under the GATS framework and modes of trade. Section 5 shows that HE development in the post-independence period relied on international cooperation to facilitate self-reliant economic development and the establishment of high quality HE institutions in India. Section 6 traces the evolution of a strategy to internationalise HE in India, while section 7 discusses forms of cross-border mobility focusing on out-bound and in-bound student mobility. Section 8 focuses on recent government initiatives to internationalise Indian $\mathrm{HE}$ and the final section draws conclusions from the analysis.

\section{Internationalisation as an Extension of Foreign Aid}

Internationalisation of education implies the imparting of knowledge, skills, and values that have universal application. It is a process of integrating an international, intercultural, and global dimension into the purpose, functions (teaching, research, and service), and delivery of HE (Knight, 2004). Internationalisation promotes interactions within and between cultures so that the curriculum becomes cross-national and intercultural in nature.

Internationalisation can take place both at home and abroad. The former is a campus-based activity that does not involve cross-border movement of persons or programmes, while the latter implies cross-border movement of programmes, students, institutions and teachers (Knight, 2006). Although activities involving cross-border movement only form a small part of global $\mathrm{HE}$, they remain central to current discussions on internationalisation. However, internationalisation of the curriculum and the teaching and learning process (internationalisation at home) are also embraced by countries (De Wit, 20II).

The motivations for internationalisation have changed during different phases of development. Academic interests and the pursuit of knowledge defined its early stages while, in the post-colonial period, internationalisation was regarded as a mechanism to facilitate self-reliant national development. In the context of globalisation, internationalisation has become a market mediated activity involving millions of students and billions of dollars. 
In the medieval period, universities functioned as international institutions that attracted international students and professors and employed an international language (Latin) as the language of academic discourse and communication (Altbach, I998). Modern national boundaries and restrictions on movement did not exist. However, communication was limited to a certain catchment area and face-to-face interactions were the most common mode of interaction. Students moved to locations where renowned teachers were available and teaching was the major, if not the only, source of knowledge. Teachers and students stayed in the same place and learning and living were intertwined. The quest for knowledge and the students' aspirations to learn from renowned teachers were the major motivations for internationalisation of learning.

Higher education developments in the post-World War II period were influenced by the need for reconstruction and development in newly independent countries. Graduates played an important role by providing the necessary skills to facilitate economic growth and social development. In the newly liberated countries, internationalisation was motivated by the need to nurture skills to manage the economy and a vision for a national education system.

These newly independent countries adopted strategies to nationalise and indigenise development (Atal, I995) with the support of international agencies and bilateral cooperation projects. Such collaborations were facilitated by the fact that many of their leaders were educated abroad. This was the case for $57 \%$ of the leaders of the II 3 countries surveyed by Spilimbergo (2009).

Indigenisation of national development in the newly independent countries had two important dimensions, namely, developing professional competencies to lead the country towards self-reliant development as high ranking decision making positions in many countries were held by expatriates, and designing national education systems. One of the primary objectives of expansion of HE in Africa was 'Africanisation' (Shutton, I97I) of development. Universities in these countries not only "symbolized national pride and self-respect" (Coleman and Court, I993) but also represented aspirations for national self-reliance.

Replacement of expatriate teachers by nationals was necessary to promote a national system of education. National universities and HE institutions also played an important role in developing school education through designing a national curriculum, training teachers and promoting national languages. Since many of the newly independent countries did not have well developed universities, they relied on training nationals abroad or inviting foreign faculty to lecture at their universities. Internationalisation efforts helped to achieve these objectives.
For their part, the governments of developed countries regarded internationalisation in $\mathrm{HE}$ as an extension of foreign policy and aid to sustain diplomatic relationships with the newly independent countries. The most visible forms of internationalisation at this stage were cross-border education through cooperation projects, academic exchange programmes and scholarships (Knight, 2006). Scholarship programmes such as USAID and the Fulbright programme, the Colombo Plan, British Council and Commonwealth scholarship programmes, and the German Academic Exchange Service (DAAD) are examples of initiatives designed to promote internationalisation of HE in less developed countries. Thus in its initial stages, internationalisation was seen by developed countries as an extension of foreign aid and technical assistance to developing countries (Varghese, 2010).

Many students and faculty members of universities in less developed countries studied abroad under various programmes. While some returned and contributed to the development of $\mathrm{HE}$ and research in their home countries, many remained abroad. In general, most of those that studied in the US did not return while a good number of those that left for studies in Europe returned (Teferra, I997). Nonetheless, international collaborations helped the newly independent countries to develop national capacity to formulate policies and plans, and to create institutional structures to educate their citizens.

\section{Internationalisation in the Context of Globalisation}

In the context of internationalisation for national development, the basic unit of production and transaction remained the nation, with goods and services nationally produced and distributed among nations. In contrast, globalisation has resulted in integration of national economies into a global economy, mainly through free trade, and free mobility of capital and labour. It involves the effective erasure of national boundaries for economic purposes (Daly, I999). In this context, the role of HE has changed dramatically from focusing on national development to producing graduates for global labour markets.

The development strategies of the I980s relied on market forces to globalise production. Knowledge economies relied on highly skilled workers which the educational systems in many countries could not produce. Countries were left with two options (Varghese, 2013): a) educate citizens at home; or b) hunt for talent abroad. The second option was easier, faster and cheaper and knowledge economies encouraged migration of highly skilled personnel from developing to developed countries. The hunt for global talent intensified the 'battle for brains' (Chandra, 2002) to promote national competitiveness and global production. Many countries intro- 
duced new forms of visas to promote migration of highly skilled personnel.

In some senses, globalisation glorified commodification of education and trade in education (Galway, 2000). Through its strategies of commercialisation, privatisation, and capitalisation, it has facilitated a business takeover of education. While it has been argued that internationalised education prepares students for an interdependent world (Cudmore, 2005), the traditional view of internationalisation with its focus on academic gains and as part of foreign aid, has been replaced by a view that prioritises market values and financial gain.

In the context of globalisation, education became a commodity to be traded under the GATS framework. Economic rationality and commercial interests became the driving force to promote cross-border flows in education and the production of graduates for the global labour market. Universities focused on imparting globally accepted, standardised skills and international languages. Qualification frameworks and instruction in English became common. English became the 'Latin of the $2 \mathrm{I}^{\text {st }}$ century' and lack of proficiency in this language "seriously disenfranchised" (Mathews, 20I3) graduates seeking jobs in the global market.

In this market mediated process, education is traded through four modes under the GATS framework: a) cross-border supply of services where consumers do not cross borders. E-learning-based distance education programmes, on-line universities and massive open online courses (MOOCs) are good examples of this mode of trade; b) consumption abroad where consumers (students) cross borders, which is the most visible form of this mode of trade; c) the commercial presence of the provider in another country in the form of branch campuses or twinning and franchising arrangements between cross-border universities; and d) the presence of persons in another country to provide the service, the most visible form of this mode being the mobility of professors from one country to another.

\section{Globalisation and Cross-Border Mobility}

Student mobility is the most visible and traditional form of internationalisation. In 2017 more than 5.09 million students (UIS, 20I8) were pursuing HE in foreign countries. The most common direction of crossborder student flow is from developing to developed countries. A group of nine countries in North America and Western Europe hosts nearly 60\% of cross-border students, with the US hosting the largest number and share. It seems that post-study visa facilities and employment opportunities influence students' choice of a destination country. These decisions are led by the economic returns on household investment in study abroad. From the host country's perspective, student mobility has become a reliable avenue for recruiting future highly-skilled workers in many developed countries
(Tremblay, 2002), especially since many students would like to remain and work in the host country (Kapur and McHale, 2005).

Internationalisation through institutional mobility is a phenomenon of the current century. It takes place through branch campuses, franchising or twinning arrangements (Cao, 20II). Branch campuses act as education hubs, attracting students seeking cross-border education within the country and abroad. Countries and cities such as Malaysia, Singapore, Hong Kong, Abu Dhabi, Dubai, Doha, Qatar and Mauritius are examples of education hubs. Students prefer branch campuses because of the low cost, market friendly courses, favourable employment opportunities, and a familiar culture and living conditions (ACE, 2009; Wilkins and Balakrishnan, 20I2). Programme mobility is a fast growing segment of internationalisation, especially since the emergence of MOOCs. Growth in enrolment in MOOCs has been exponential and is changing the landscape of global HE provision (Yuan et al., 2008). Rapid expansion of MOOC courses and technological advances have encouraged the introduction of online courses in developing countries (Varghese, 20I7). Investors are also influencing national governments to adopt regulatory provisions that enable more flexible study programmes and delivery modes (Levine, 20I3). Platforms for MOOCs, online courses and digital modes of communication have become widespread and are now the most common mode of learning.

\section{Internationalisation of $\mathrm{HE}$ in India}

Indian HE has experienced massive expansion and revival since the turn of the century. The sector has transformed from a slow growing one with low enrolment into a massified system. In 20I8, student numbers increased by more than 4.5 times to reach 36.8 million, the number of colleges more than quadrupled to 40,000 and the gross enrolment ratio reached $26.2 \%$ (MHRD, 20I9). The large education market in India is a source of financial gain for many countries interested in trade in education services.

The international interface in Indian education has a long history. In the $7^{\text {th }}$ century AD, the ancient Indian university of Nalanda was an international centre with I0,000 students and 2,000 professors. It attracted students and teachers from China, Indonesia, Korea, Japan, Persia and Turkey.

The international influence on Indian HE continued during the colonial period, with universities established during these times modelled on British universities. For example, the first three universities established during the colonial period were modelled on London University. The country also relied on foreign countries, especially the UK, for teachers and training of Indians as faculty members, as well as for laboratory equipment and facilities. Furthermore, India hosted several missionary HE institutions during this period, including St Joseph's College, Trichy, St Xavier's, 
Chennai, Christian Medical College, Vellore, St John College, Agra, and Isabella Thoburn College, Lucknow (Singh, 20I6).

Internationalisation for Institutional Development

In the post-independence period, internationalisation of HE initially took the form of cross-border flow of students, teachers and financial flows to establish HE institutions. These cross-border flows can be broadly classified into three forms. The first was the flow of students and teachers to universities abroad for studies. Although some did not return, many did and established research laboratories or departments in Indian universities. The first generation professors in many of India's prestigious institutions were trained abroad. This remains true today of many professors in top ranking institutions.

The second cross-border flow was of professors from foreign universities to Indian HE institutions. Thirdly, government-to-government cooperation and collaboration initiatives were launched to establish HE institutions in India. The establishment of top ranking technical and professional institutions in India clearly indicates the three forms of international support received.

In the post-independence period, India adopted a planning framework for self-reliant development. Five-year plans were formulated to define the direction of change and development in the country. Acknowledging that technological advancement is an essential step in self-reliant development, India laid the foundation for its Institutes of Technology (IITs) in the I950s. While the government drew on external funding and expertise from developed countries, this was framed within a non-alignment political context.

The first IIT at Kharagpur in West Bengal that was established in I95I, drew faculty members from the US and several European countries. The IIT Bombay received experts and substantial financial support from the USSR through UNESCO, which also offered fellowships to train Indian faculty members abroad. The IIT Madras received similar support and fellowships from Germany, while the IIT Kanpur received technical assistance from a consortium of nine leading US institutions to establish the institution, its academic programmes and laboratories for instruction and research. The IIT in Delhi was established with the help of the British government. Indian Institutes of Management (IIMs) were also established in collaboration with the Harvard Business School.

Many of the first generation professors in Indian universities were educated abroad, where they were exposed to global teaching practices and research. Even today, numerous high quality institutions have a relatively high proportion of faculty with teaching and research experience abroad.

\section{Evolving a National Strategy for Internationalisation}

While internationalisation of HE in the initial years after independence reflected the political commitment to technologically self-reliant economic and industrial development, India did not have a long-term strategy for such internationalisation. The two national policies on education in India, which were adopted in I968 and I986 did not consider internationalisation of education as an important domain or priority area. Internationalisation as a deliberate policy and strategy evolved in India in the current century. During the formulation of the $10^{\text {th }}$ five-year plan (200I-06), the University Grants Commission (UGC) articulated the need for internationalisation, focusing on the cross-border flow of students. It introduced an initiative called 'Promotion of Indian Higher Education Abroad (PiHead)' that aimed to attract foreign students to Indian campuses through awareness campaigns and educational fairs abroad.

The Association of Indian Universities (AIU) formed a Task Force on internationalisation of $\mathrm{HE}$ in 2004 that concluded that it is not in the interests of the country to open up its HE system to global competition under GATS (Sharma, 2008). In 2006, the UGC formed a study group on internationalisation and recommended the establishment of a Consortium for International Education at the UGC, AIU or any university in Delhi. In 2009 , the UGC prepared a plan on internationalisation of $\mathrm{HE}$ and in the same year, the National University of Educational Planning and Administration (NUEPA) organised a national consultation meeting on foreign $\mathrm{HE}$ providers in India.

The $12^{\text {th }}$ five-year plan (20I2-I7) included proposals for faculty and student exchange programmes, and collaborations for teaching and research. It was also envisaged that a professional national agency, the 'India International Education Centre' would be created to undertake internationalisation activities including setting up internationalisation units in universities. Many of these initiatives lacked strong political support, administrative direction and financial backing and consequently did not come to fruition.

\section{Internationalisation and Modes of Cross-Border Mobility}

In recent years, India has been active in internationalising its HE sector. It ranks second in the world in terms of sending students abroad for studies and in enrolment in MOOC courses. A large number of Indian professors teach in foreign universities. However, foreign universities were not permitted to establish and operate independent branch campuses in India. The New Education Policy (NEP 2020) suggests that this may be permitted. All in all, India has been very favourably placed in terms of three of the four modes of cross-border mobility, namely, student, programme and teacher mobility. 


\section{Indian Students Abroad}

The number of Indian students abroad has increased consistently, indicating the importance attached to studying abroad by households. The number of Indian students abroad increased 5.2 times from 66.7 thousand in 2000

to 305 thousand in 2017 , representing an average annual growth rate of $9.4 \%$. India is the second largest student-sending country after China.

In ig95 more than $85 \%$ of Indian students abroad were hosted by three countries, namely, the US, UK and Canada. In 20I8, these three countries accounted for only $56 \%$ of Indian cross-border students. The US remains the leader in hosting Indian students, although its share declined sharply from $78.5 \%$ in I995 to $44.4 \%$ in 2018 (Table I). However, it should be noted that the number of students studying in the US continues to increase. The new player on the scene is Australia which consistently increased its share in hosting Indian students from $5.2 \%$ in 2004 to $17.0 \%$ in 2018 . The number and share of Indian students hosted in the UK declined sharply from I9\% in 2010 to $5.4 \%$ in 2018 . These changing trends in Indian student flows indicate a close association between the choice of study destination and the potential for higher returns on investment.

In the present day context, Indian students' studies abroad are mainly funded by households. Indian students have become 'highly-price-sensitive' and 'value maximisers' in choosing a destination country. They seek options that cost less, and enhance career opportunities and returns on investment. They continue to opt for English-speaking countries which offer good international education and job opportunities after studies. The cross-border flow of Indian students reflects this preference.

The share of Indian students studying in the US has been very high as it provides opportunities for good placements after studies (Optional Practical Training, OPT). However, when avenues opened in Australia and Canada with lower costs and favourable post-study visa opportunities for employment, Indian students' flow to these countries increased (Table I). The Post-Graduation Work Permit Program (PGWPP) introduced in Canada in 2006 and Australia's point-based immigration policies are examples of this trend.
Table 1. Changing Destinations of Indian Students Abroad (\%)

\begin{tabular}{|l|c|c|c|c|}
\hline Host Countries & 1995 & 2004 & 2010 & 2018 \\
\hline US & 78.5 & 67.6 & 51.8 & 44.4 \\
\hline UK & 5.5 & 10.6 & 19.0 & 5.4 \\
\hline Canada & 2.6 &.. & 2.3 & 6.5 \\
\hline Australia &.. & 5.2 & 10.2 & 17.0 \\
\hline
\end{tabular}

UIS (different years)

The decline in Indian student flows to the UK after 20I0 when it abolished post-study work visas (Choudaha, 20I9) and an increase in enrolment of $93 \%$ in 2019 when the UK revised the post-study visa rules, confirm that outbound Indian student flows are highly influenced by returns on investment.

\section{Foreign Students in India}

India hosted 46,703 foreign students in 2018 (Table 2). While Indian students abroad account for $6 \%$ of the total, foreign students in India account for $0.9 \%$ of internationally mobile students. Although there is provision for foreign students to constitute $15 \%$ of total enrolment in some Indian $\mathrm{HE}$ institutions and IO\% across the sector, these targets remain a dream. If one considers Io\% of total enrolment as a target, India could have enrolled 3.6 million foreign students. The figure currently stands at less than 0.13\%. This situation is due to low demand for study in Indian programmes rather than availability of places.

Most of the foreign students in India are from neighbouring countries or from Africa (Table 2). The single largest share of students in 2018 came from Nepal and more than half of the international students in India come from seven countries (Table 2). Higher education institutions in the sending countries might be less prestigious and of lower quality than those on offer in India. 
Table 2. International Students in India, 2018

\begin{tabular}{|l|c|}
\hline Country of Origin & \% of the Total \\
\hline Nepal & 22.5 \\
\hline Afghanistan & 9.5 \\
\hline Bhutan & 4.8 \\
\hline Nigeria & 4.5 \\
\hline Sudan & 4.4 \\
\hline Malaysia & 3.5 \\
\hline Bangladesh & 3.3 \\
\hline Total & 52.5 \\
(in ooos) & 46.70 \\
\hline
\end{tabular}

Source UIS (2019)

Several positive factors attract foreign students to India. Fee levels are low as is the cost of living. The factors constraining international students include the lack of post-study visas and employment opportunities, low salaries and adverse reports on safety, especially of female students. India offers highly subsidised education to international students. However, while the cost is low, the returns are also low, making this model unattractive to foreign students.

Institutional Mobility and Collaborations

India has benefitted from international collaborations to establish HE institutions such as the IITs and IIMs. Many foreign institutions are keen to establish branch campuses in the country to take advantage of the expanding student market. However, as noted earlier, the government of India does not permit independent branch campuses, but allows institutional collaborations. Bhushan (2005) found that there were I3I foreign-affiliated institutions in India, most in partnership with universities in the UK and the US. Another study (AIU, 20I2) showed that the number of foreign collaborations with Indian HE institutions increased from I44 in 2000 to 63I in 20I0. The largest number of collaborating institutions were from the UK (I58), followed by Canada (80) and the US (44). However, it seems that many of the collaboration arrangements were not approved by the regulatory authorities (Dhavan, 2012).

Several high-level delegations have visited India to establish institutional collaborations and branch campuses. The British Prime Minister, accompanied by educational leaders from several UK universities visited India on several occasions in the past two decades. The total estimated investment in collaborative ventures is valued at around USD I52 million. Similarly, the president of France accompanied by HE authorities signed I7 university collaboration agreements (Misra and Sharma, 2013).

Many Indian institutions have established campuses abroad. The JSS Academy of Technical Education and DY Patil Post-Graduate School of Medicine have established campuses in partnership with the University of Technology in Mauritius (UTM). An off-shore campus of Manipal University operates in Malaysia and Dubai, and Amity University has campuses in the UAE, US, UK, China and Singapore. Four Indian private institutions are represented in the Dubai International Academic City (Mathews, 20I4). It seems that the newly established private institutions are keen to establish collaborations with institutions from foreign countries. These collaborations are marketing strategies to attract more local students and levy high fees to maximise their revenue and profit (Altbach and Mathews, 20I5). The main attractions for students are a foreign degree at lower cost, opportunities to gain international experience through exchange programmes, access to extensive online resources and more importantly, less strict admission criteria.

One advantage that India has over other countries is its large Diaspora population in many countries across the globe. In 20 I9 India had the largest Diaspora of 32 million, comprising of people of Indian origin and non-resident Indians. Many members of the Diaspora are highly educated, and well placed and are keen to invest in their children's education. This forms an attractive segment of the student market for international education.

\section{Recent Initiatives for Internationalisation of $\mathrm{HE}$}

The Indian approach to internationalisation of HE neither stems from GATS nor is motivated by commercial interest or revenue generation. Rather, it is seen by the government as a means to extend soft power and diplomatic relationships with foreign countries on the one hand, and as a means to enhance India's position in the global ranking of universities on the other.

The government of India has taken various steps to expand the scope and operations of internationalisation of HE. Its efforts to develop India as an education hub are part of this strategy. To attract international students, the government launched the 'Study in India' programme in 2017 with provision for 2,500 scholarships. It attracted around 6,000 students from more than 30 countries in 2018 and more countries are expected to be covered in future.

India has set a target of 500,000 international students by 2024 . The government is also expanding student support facilities. For example, the number of student scholarships will be increased to 50,000 by 2024 . India 
is also exploring the possibility of passing legislation to permit foreign universities to establish independent branch campuses in the country. This may attract more foreign students to India.

Another programme was launched in 20I7-I8 to attract foreign faculty members to teach for short periods in Indian universities. The Global Initiative for Academic Network (GIAN) attracted around I,800 scholars from 56 countries to offer courses in 20I7-I8 and 20I8-I9. In its extension in GIAN II, the government intends to promote mobility of Indian faculty members to teach in universities abroad.

A Scheme for Promotion of Academic Research and Collaboration (SPARC) was launched in 2018 to promote research collaboration between reputed institutions abroad and Indian institutions. Such collaboration enhances the academic credibility of domestic institutions, increases Indian faculty members' international publications, and promotes international exposure and experience which encourages adherence to international standards in teaching and research, and helps to develop a comparative perspective and enhanced analytical competencies (Varghese, 20I5).

India's MOOC platform SWAYAM (Study Web of Active Young Aspiring Minds) is also gaining popularity. The SWAYAM courses are offered to foreign students and it has the potential to attract foreign students in large numbers.

\section{Concluding Observations}

Knowledge is produced nationally, but shared globally. There is thus a need for Indian HE institutions to remain globally connected and engaged. International collaborations and cooperation in knowledge production and sharing are important steps in enhanced visibility to gain international academic credibility. It is important to take advantage of the opportunities provided by international collaborations to place Indian HE in the global context.

The internationalisation taking place under the GATS framework regards HE as a commodity to be traded. The Indian approach to internationalisation does not stem from a trade perspective or from a motive to generate revenue. Indeed, India is providing fellowships to a number of international students and highly subsidised HE to all such students. The objective seems to be to establish diplomatic relationships with many countries and to play a more visible global role.

The focus of internationalisation in India is to attract more students to the country and to develop it as an education hub. This requires changes in the regulations to offer post-study visas as well as curriculum changes to make the country's educational offerings more attractive and enhance the global market value of graduates from Indian institutions. It implies that India needs to focus not only on internationalisation abroad but also at home. The NEP 2020 envisages the production of globally competitive and nationally grounded university graduates. New initiatives such as the GIAN and SPARC may promote internationalisation at home by engaging foreign trained professors, establishing collaborations with foreign universities, and by revising the curriculum to make it globally relevant.

\section{References}

Altbach, P.G. (1998). Comparative higher education: Knowledge, the university and development. Greenwich: Ablex Publishing Corporation.

Altbach, Philip, and Mathews, Edho. (2015). India's Need for Higher Education Internationalization. International Higher Education 82,23-24.

ACE: American Council of Education. (2009). U.S. Branch Campuses Abroad. ACU Brief, September.

AIU: Association of Indian universities. (2012). Foreign educational providers in India, 2010. New Delhi, India: AIU.

Atal, Yogesh. (1995). Higher education capacity building and social development for the $2 \mathrm{I}^{\text {st }}$ century. In: UNESCO (ed.) Higher education and capacity building for the $21^{\text {st }}$ century, pp. 77-84. Paris: UNESCO.

Bhushan, S. (2005). Foreign universities in India: Market-driven new directions. International Higher Education 41, 4-5.

Cao, Y. (20II). Branch Campuses in Asia and the Pacific: Definitions, challenges and strategies. Comparative International Higher Education 3,8-Io.

Chanda, R. (2002). GATS and its implications for developing countries: Key issues and concerns. DESA Discussion Paper No. 2 (Department of Economic and Social Affairs, UN, New York).

Choudaha, R. (2019). Study abroad trends of Indian students to USA, UK, Australia and Canada. Dr Education: Global higher education trends and insights, 29 January.

Coleman, James, and Court, David. (I993). University Development in the Third World: The Rockefeller Foundation experience. Oxford: Pergamon.

Cudmore, Geoffrey. (2005). Globalization, Internationalization, and the Recruitment of International Students in Higher Education, and in the Ontario Colleges of Applied Arts and Technology. The Canadian Journal of Higher Education 55(I), 37-60.

Daly, Herman. (I999). Globalization versus Internationalization. New York: Global Policy Forum.

De Wit, Hans. (20II). Globalization and Internationalization of Higher Education. School of Economics and Management, Hogeschool van Amsterdam, University of Applied Sciences.

Dhavan, H. (20I2). "UGC to let only top 500 foreign universities enter India." Times News Network December I6. 
Edwards, Sebastian. (20I4). Development and the effectiveness of foreign aid: a historical perspective Working Paper 20685. National Bureau of Economic Research (NBER), Massachusetts.

Galway, A.D. (2000). Going global: Ontario Colleges of Applied Arts and Technology, international student recruitment and the export of education. Toronto, ON: Ontario Institute for Studies in Education, University of Toronto.

Kapur, D., and McHale, J. (2005). Give us your best and brightest: The global hunt for talent and its impact on the developing world. Baltimore: Brooking Institution Press (for Centre for Global Development).

Knight, J. (2004). Internationalization remodeled: Definitions, rationales, and approaches. Journal of Studies in International Education 8(I), 27-37.

Knight, J. (2006). Higher education crossing borders: A guide to the implications of the GATS for cross-border education. Paris: UNESCO/Commonwealth of Learning.

Levine, A. (20I3). "MOOCs, history and context." Inside Higher Ed, 29 April.

Mathews, D. (20I3). "Expansion causing 'chaos' across the world." Times Higher Education, I2 April.

Mathews, Eldho. (20I4). Internationalization: Where is India Headed? Inside Higher ED, September 25

MHRD: Ministry of Human Resource Development. (2019). All India Survey of Higher Education 2018-19, New Delhi. MHRD.

Misra, A., and Sharma, Y. (20I3). UK, France vie for research collaboration with India. University World News 2(26I).

Moyo, D. (2009). Dead aid: Why aid is not working and how there is a better way for Africa. New York, NY: Farrar, Strauss and Giroux.

Sharma, Kavita. (2008). Internationalization of Higher Education: An aspect of India's foreign relations. New Delhi: Gyan Publications.

Singh, Shailendra. (2016). Impact of Globalization on Higher Education in India: Issues, Challenges and Alternatives. The International Journal of Indian Psychology 3(2),24-30.

Spilimbergo, A. (2009). Democracy and foreign education. American Economic Review 99(I), 528-43.

Sutton, F. (I97I). African universities and the process of change in Middle Africa. In: Kertesz, S.D. The task of universities in a changing world, pp. 383-404. Notre Dame: University of Notre Dame.

Teferra, Damtew. (I997). Brain Drain of African Scholars and the Role of Studying in the United States. International Higher Education7 (Spring I997), 4-6.

Tremblay, K. (2002). Student mobility between and towards OECD countries: A comparative analysis. In: Organization for Economic Co-operation and Development (OECD) International mobility of the highly skilled, pp. 39-70. Paris: OECD.
UIS. (several years). Global Education Digest: Comparing education statistics across the world. Montreal: UIS.

Varghese, N.V. (2010). Higher education aid: setting priorities and improving effectiveness. Journal of International Cooperation in Education 13(2), I73-87.

Varghese, N.V. (2013). Globalization and higher education. Analytical Reports on International Education 5(I), 7-20.

Varghese, N.V. (20I5). BRICS and international collaborations in higher education in India. Frontiers of education in China, 10(I), 46-65.

Varghese, N.V. (20I7). Internationalization and cross-border mobility in higher education. In: Egetenmeyer, Regina, Guimaraes, Paula and Nemeth, Balazs (eds) Joint modules and internationalization in Higher Education, pp. 2I-38. Frankfurt: Peter Lang.

Wilkins, S., and Balakrishnan, M. (20I2). How well are international branch campuses serving students? International Higher Education 66,3-5.

Yuan, L., MacNeill, S., and Kraan, W. (2008). Open educational resources opportunities and challenges for higher education. Retrieved from: http:// wiki.cetis.ac.uk/images/o/ob/OER_Briefing_Paper.pdf I-34. Abstract 